\title{
The Reform of the Albanian Legal System Between Challenges and Problems, With Particular Focus on the Criminal Justice Issues
}

\author{
Ersi Bozheku \\ Professor of Criminal Law, Doctoral School of Public Law, \\ Faculty of Law, Sapienza University of Rome, \\ Piazzale Aldo Moro, 5, 00185 , \\ Roma RM, Italy

\section{Enida Bozheku} \\ Lecture of International Criminal Law, \\ Faculty of Law, Luarasi University of Tirana, \\ Rruga Dritan Hoxha 127/1, \\ Tirana, 100o, Albania
}

DOI: https://doi.org/10.36941/ajis-2021-0169

\section{Abstract}

This article aims to carry out an analysis of the problems affecting the legal system, with particular reference to the criminal law and criminal procedure law, of the Republic of Albania. We will start from a rapid reconstruction of the Albanian system in a historical key to understand its peculiarities, to move on to the most significant steps in its evolution. At a later stage we will try to highlight the critical issues that have arisen not only on the level of criminal law, but also on the cultural one. The reasons that led to the 2016 constitution reform and then to the subsequent reforms that changed the face of the country's legal system will be highlighted. Will be highlighted. The news, the improvements and the problems related to the knowledge of the law and above all to the ability to create a law capable of being systematic. In this perspective, we will try to understand the reasons that still leave many perplexities on the Albanian reform path. the improvement of the justice system represents the central point for Albania to successfully undertake the path of accession to the European Union.

Keywords: Judicial system, reforms, law, Supreme Court, Costitutiona Court, Attorney General, Vetting, Criminal Law, Criminal Procedure Law

\section{Introduction}

In recent years, Albania has been at the center of a strong socio-cultural and then political-legal debate in relation to the structure of its justice system. This led the Parliament of the Republic of Albania to unanimously approve a profound justice reform which affected the entire legal system of the country (Bozheku, 2016). The legislator intervened in an incisive way on the constitution by modifying a large part of the judicial organizational structure. The supporting structures of the system have been changed, such as the choice of the members of the Supreme Court, the choice of 
the members of the Superior Council of the Judiciary, etc. In this case, two Superior Councils have even been envisaged: The Superior Council of the Public Prosecutor's Office and the Superior Judicial Council (Spangher, 2017). New structures and new rules were then provided for the correct and efficient selection of the members of the two governing bodies of the magistrates. A special body has been set up, the so-called of Vetting, for the re-evaluation of judges and with the aim of restoring citizens' trust in justice (Agaçi, 2017). The criminal procedure code (Ligori-Hoxha 2017) has been significantly changed, while a new criminal code is being implemented (Bozheku, 2017). We are therefore witnessing an important, not to say historic, moment which should launch Albania towards accession to the European Union.

\section{Research Method}

What will be analyzed in the following pages will be based on a research conducted in over 15 years. Il is based in a legal, economical, historical, political method with a focus in the Albanina Justice System. The study is divided into different parts. The first concerns the analysis of the Albanian legal framework after the conclusion of the communist dictatorship. The second concerns the problems encountered during the years of transition from 1991 to the reform of 2016 . A third part concerns the innovations brought about by the reform. The work will then conclude with a series of reflections on the challenges and possible future problems that may arise in the Albanian legal system.

\section{The Legal Transition of the $1990 \mathrm{~s}$}

Since the fall of the communist regime there has been a radical change in the structures of the state, gone from a totalitarian system to a democratic system. If until 1991 the management of power, both political and judicial, was strongly linked with the superstructures created by the Party-State, the Labor Party, with the transition to democracy we witnessed the creation of a new legal system, based on the concept of the rule of law. This new concept will be the fulcrum of the new state and no longer the party and the ideology of the class struggle, on which the communist regime laid its foundations (Bozheku, 2014).

Such a passage was very tortuous and this due to a series of factors that we will try to analyze in this paper. There have been several benefits. Albania moved from the centralized, state economy, to the free market economy; in the field of law the achievements have been remarkable (Elezi - Elezi, 2010). The lawyer has been reintroduced. The justice system has been released from the control of other structures (such as the secret services or the "Byroja politike" of the Communist Party, etc.). The country moved on to a new organization of the system. In the original idea of the reformers of the system, justice had to be autonomous in its judicial activity. On the structural organizational level, on the other hand, a system was instead thought of with a Superior Council of the Judiciary at the top, partly controlled autonomously by the magistrates themselves and partly controlled by Parliament (through mechanisms of involvement of the opposition). In this way, the aim was to ensure, on the one hand, the presence of citizens also in the judiciary and, on the other, to prevent it from becoming a corporation without any external control. The same mechanism was also provided for the Constitutional Court and the Supreme Court. The election of their members took place by the Parliament even if by qualified majority and with the consent of the President of the Republic. The School of Magistrates was then established (1997), whose task is to recruit and train new judges and public presecutors.

From the point of view of the rules, the communist codes were replaced by modern ones. In 1995 the new penal code was implemented (Belfiore 2008 Pittaro, 2008; Fondaroli, 2008; Rossi, 2008). In 1998 was implemented the criminal procedure code, very similar to the 1989 Italian one. The old superstructures of the regime, including the secret services, were dismantled and reorganized in a modern key. These will no longer have a function of controlling and repressing disobedient citizens, but of protecting their safety and the security of the state. 


\section{The Problems that Arose During the Transition Phase: The Inadequate Management of the Cultural Challenges Proposed by the New Concept of State Based on the Rule of Law}

Despite the many innovations aimed at drawing a deep furrow with the past, soon the new system also went into crisis and this due to various factors.

In the first place, the training of legal practitioners, judges, lawyers, officials or managers, was in no way adequate to expectations. The university system (the law faculties in particular) has not proved adequate to the change. Law lessons continued through the recovery of categories from the past. The role of doctrine has failed. Especially in the early 1990 os the doctrine was made up of professors trained in the old regime. These were unable to adapt to the new logical-conceptual categories of the modern State conpest base on the rule of law. Above all, they were unable to propose the conceptual categories of Western doctrine in a solid and harmonious way within the Albanian doctrinal system. This has led to the creation of a jurisprudence (which until 1991 saw in doctrine a strong anchor point) with very meager contents, unable to resolve the many and complicated legal issues that everyday reality proposes. In this scenario, even the lawyers are not exempt from blame. An extremely young class without any background, which has not been able to propose adequate questions and interpretations capable of stimulating the reflections of the judges.

\section{The Problem of Corruption}

Corruption is the most serious problem of Albanian justice. This phenomenon is strongly linked to the first. In fact, it is greatly affected by the cultural-conceptual backwardness that Albania has experienced in the field of justice in the last 30 years.

Surely the source of corruption in Albania is not represented only by the judiciary, but it is a phenomenon that has developed in recent years in all sectors of public administration. The fall of the regime, in addition to the enormous benefits, also brought many problems, including, in the first place, the modification of morals and values. Those that until 1991 were values have become disvalues and vice versa; honesty, loyalty, respect for people, respect for the weakest, respect for agreements and for the given word, sense of sacrifice, sense of duty, love of country, feeling of sharing and - above all - collectivism have given way to counter-values such as strength, arrogance, the imposition of rules from the strongest to the weakest, unbridled individualism and, above all, "money" (intended above all as the main, if not the only, source of power and social consensus ). Its discovery after 1991 led to the justification and acceptance - at least from an unconscious point of view - of counter-values such as selfishness and the abuse of power. This is obviously associated, on the one hand, with the substantial basic poverty in which all citizens found themselves after 1991 and, on the other, the discovery of well-being as the driving force of society. Therefore, the unbridled pursuit of wealth has become the goal of all, beyond one's social position: wealth has become the main tool for gaining fame and social consensus. This has obviously favored phenomena such as organized crime and corruption. If a few years earlier it was completely unthinkable (and the consequences in legal terms were very heavy) to ask for a bribe to carry out one's office duties, in a short time the phenomenon has become rampant, so much so that it assumes almost "natural" connotations.

\section{Corruption in the Judiciary}

With the advent of democracy, most of the magistrates who had covered these roles during the regime are put to rest; it feels like a necessary reform, especially to do justice to the thousands of people judged by the magistracies of communism. To cope with the emergency, new ones are recruited: young, very young, often without legal experience, who undergo six-monthly courses to cover the gaps. It was not long before the new magistrates discovered the importance of their role in the new democratic Albania. Without adequate legal training, they begin to make their first decisions 
with obvious gaps in law. Meanwhile, in addition to becoming more and more aware of their enormous power, they begin to savor the pleasure that money offers. These untouchables are joined by the new class: lawyers who very soon become the mediators of the magistrates to "fix" the trials. Decisions are becoming more and more arbitrary, while "lawyers" and "magistrates" divide up miles and thousands of euros to ensure justice for those who have more possibilities to pay. The doors of corruption are opened, while no brake is placed on this situation (Corruption in Albania, Perception and Experience, Institute for Development Research and Alternatives, 2009). The situation causes the alarm of the EU and the US State Department, which intervene with their missions to monitor and reform the justice system in Albania. The need to carry out a profound reform becomes urgent: corruption at particularly high levels prevents the development of the country and becomes a problem even for neighboring ones $\left({ }^{1}\right)$. And this is accompanied by an even more dangerous phenomenon: organized crime! The latter becomes increasingly structured, being able, thanks to the strength of money, to enjoy the impunity of the judiciary and the support of politics. In this context, however, one fact should not be overlooked (and here we return to the first point): the corruption phenomenon in the Albanian judiciary is not only favored by the loss of values and by the omitted control of the magistrates over the magistrates and of the policy on the magistrates, but above all by their lack of knowledge of the law. The problem does not only concern the judiciary as an institution, but also the individual training of judges both at universities and at their school. This, which seems to be a particularly neglected point, represents, in the humble opinion of the writer, the real problem of corruption in Albania which if it is not solved in the "school desks" will nullify all the innovative scope of the reform. as learned during his studies) is used as a justification tool for unjust sentences in the name of the motto: "we know this, so we decide" (Bozheku, 2013). In this fleeting boundary between ignorance and bad faith, the latter is the master. This is why - in this perspective - the problem of corruption of magistrates in Albania is particularly complex and not easy to solve even for the generations to come.

\section{The Influence of Politics on the Judiciary}

A factor that has determined the need for reform of the Albanian legal system is represented by the strong interference in the judiciary by politics19. The choice of judicial magistrates in the last twentyfive years has been strongly affected by its influence (Commission of Venice CDL-AD (2010) 040). For example, the Supreme Court before the 2016 reform had a very problematic settlement. Its members were not career magistrates but jurists chosen through a complicated mechanism that involved Parliament and the President of the Republic (Bozheku, 2013).

More precisely, pursuant to the old article 136 of the Italian Constitution Alb. (now reformed) the judges of the Supreme Court were directly appointed by the President of the Republic after approval by the Parliament in simple session and by simple majority; the same procedure was also envisaged in relation to the appointment of the President of the same Court (Analytical document on the justice system in Albania, in reformanedrejtesi.al.). The situation was paradoxical. The Supreme Court had direct jurisdiction as a first and only instance judge in relation to crimes (all, regardless of whether in the performance of their functions or not) committed by parliamentarians, ministers and some senior state officials. In short, the Supreme Court was chosen by Parliament and had to decide on the crimes of its members.

Problem was also the supervisory body of the judges, the Superior Council of Justice. The President of the Republic attended its meetings not in a symbolic capacity but by participating in

1 In the 2014 annual report on Albania, the European Commission highlights among the main problems of the Albanian justice system the high rate of corruption, the strong politicization of judges, the existence of an unclear and poorly functioning system in terms of appointments, transfers, disciplinary measures against judges and prosecutors, etc .; On point v. European Commission, 2014 Progressive Report for Albania, p. 53 ss.. 
decisions.

Problem was also the figure of the Attorney General, also known as the Super-Procurator. He represented the top of the prosecution body and was directly chosen by consensus by the President of the Republic and the Parliament (Article 148 of the 1998 Italian Constitution). In addition to the power to carry out investigations to himself, or to assign them to prosecutors, he could dispose of their transfers as well as disciplinary sanctions.

The Attorney General also had the right to propose the appointment and / or dismissal of prosecutors to the President of the Republic (Article 149 of the 1998 Italian Constitution). Therefore, the prosecution body was strongly linked to the figure of its top management, who in fact chose their collaborators; in turn, the Attorney General was chosen by the political power. In practice it happened that, when the Attorney General and the President of the Republic were chosen by the same majority, the prosecutors were chosen from people politically close to the majority party, with a consequent lowering of the overall level of the prosecution body.

In short, the 1998 Albanian Constitution was one of the main sources of the problem... !!! The conferral of shared power between the President and Parliament in identifying the leaders of the system, which was to act as a guarantee for the choice of the best men, was a major failure. The entrusting of the management of the judiciary to politics has led to a strong politicization of the judiciary, especially in the legislatures in which the majority also elected the President of the Republic. The deep dependence on political power has often led to suspicious decisions by judges. There have been cases in which the prosecutors, rather than responding to concrete needs of justice, have initiated criminal proceedings aimed at satisfying factional interests and targeting uncomfortable political figures. Often corrupt politicians enjoyed impunity precisely because they could rely on the benevolence of trusted magistrates from their own political current. After all, the Supreme Court - of political election - could decide their crimes (including common ones and released from the exercise of their functions) as first and only degree judge.

Over time, a similar situation has led to the degeneration and collapse of the system. Citizens have totally lost faith in the judiciary, seeing it as an instrument of oppression as well as protection of the strong powers. News phenomena such as the release of criminals caught in the act of very serious crimes, or the acquittal of talked about politicians has led to exasperation not only the Albanians but also their international partners: both the EU and the US State Department in fact, they are increasingly concerned about the situation of justice in Albania.

\section{The Constitutional Reform of 2016}

Faced with the above problems, in 2016 the Albanian Parliament approved a radical constitutional reform of justice in Albania. It was born following a complex legislative process. A parliamentary reform commission is first established, which will appoint a group of high-level experts with the task of coordinators and, again on the nomination of the parliamentary commission, a further group of Albanian and foreign experts coordinated by the former. It was a particularly complex procedure where there was a continuous confrontation between both local and international experts.

The guiding lines of the reform are four: a) the reduction of the influence of political power on the judiciary; b) the restoration of citizens' trust in the justice system through a series of control mechanisms capable of targeting corrupt magistrates at all levels and guaranteeing the professionalism and clarity of the new ones who will replace them; c) the creation of suitable mechanisms to avoid institutional impasse regarding the choice of the highest representatives of the central organs of the justice system; d) the identification of criteria aimed at increasing the subjective and objective quality of both judges and senior officials of the legal system.

In this perspective, the structure of the Court of Cassation, the Constitutional Court, the Superior Council of Justice (which changes its name to the Superior Judicial Council) has been redesigned, as well as the role of the President of the Republic and his prerogatives have been revised. in matters of justice. In addition, new constitutional bodies have been established: the Superior 
Council of the Prosecutor's Office, the High Inspector of Justice, the Special Prosecutor's Office and the Special Court for High Crimes as well as for crimes committed by politicians and senior state officials, the Council for Appointments in Justice and, on a transitional basis, two first and second degree commissions (known as "vetting") which will have to examine all the dossiers, professional and personal conduct and assets of the individual magistrates currently in service.

\section{The Constitutional Changes: The New Institutions and the New Faces of the Existing Ones}

With the constitutional reform of the judicial system, the Albanian legislator has set itself the goal of reducing the influence of political power on the judiciary through the creation of suitable mechanisms to avoid institutional impasse regarding the choice of the leaders of the judiciary. Another objective is to restore citizens' trust in the justice system, both through a series of control mechanisms capable of targeting corrupt magistrates at all levels and guaranteeing the professionalism and clarity of the new ones (who will replace them), and through the identification of some minimum criteria capable of increasing the subjective and objective quality of the same.

With reference to the two Supreme Councils of Justice, it was decided to create two totally autonomous bodies, independent of each other, or from other bodies. Both will deal with the administration of power, respectively, of the judicial and investigating magistrates and in particular of training, evaluation, appointment, transfers, disciplinary measures, etc. of judges and prosecutors. They will be composed of eleven members each, six of which will be elected, respectively, by and among judges and public prosecutors, while five members will be chosen by parliament from among non-professional jurists. The Constitution in articles 147 (ref. 2016), as regards the Judicial Superior Council (JSC), and 149 (ref. 2016) in relation to the Superior Council of the Prosecutor's Office (SCPO), provides for a complicated procedure in relation to the choice of the five non-professional members. In particular, it is established that two must come from the world of law, two from the faculty of law and the School of the Judiciary and one from civil society. The choice will have to fall on prominent personalities and mirrored conduct with over fifteen years of experience. To avoid arbitrary choices, the Secretary General at the Parliament will have to launch a public announcement in relation to the post that has remained vacant. Within ten days of the presentation of the candidacies, he must verify whether the candidates meet the requirements set out in the Constitution, arranging a list where he excludes those who are unsuitable. Immediately afterwards, he will have to send the list with the names to the Parliamentary Commission for Legal Affairs, which, within three days, will have to appoint a subcommittee composed of five deputies, three from the majority and two from the opposition. With four votes in favor, the subcommittee may decide to include in the list also the candidates excluded by the Secretary General of the Parliament. It chooses the candidate (s) with a majority of four votes. If the quorum is not reached, the candidate (s) will be drawn by lot. The list with the name (s) will then be sent to the Parliament which will decide by a majority of $2 / 3$ of all parliamentarians within ten days. If the quorum is not reached, the procedure will have to be repeated, but not more than twice. If the Parliament does not approve after the third vote, the last list of candidates will be deemed approved ex lege $\left({ }^{2}\right)$.

With the 2016 reform, the composition of the Supreme Court has also changed radically. In the

2. The members of JSC and SCPO remain in office for five years and are not immediately re-eligible and, once their office has ceased, they resume service in the offices previously occupied. Contrary to the past, their president will have to be chosen at the first meeting by the same members from one of those not togates (before instead the President of the Republic proposed it and the Parliament approved it). They can be removed from their post by the Constitutional Court in the event of serious ethical or professional violations, or of definitive conviction for a crime (they are suspended, however, in the event of arrest, or when they assume the capacity of defendants in criminal proceedings for willful crimes). 
first place, its members will no longer be chosen by parliament from among the laity, but by the Superior Judging Council (SJC) from professional judges with more than thirteen years of career for a term of office of nine years, without the possibility of re-election. The appointment will be formally decreed by the President of the Republic, who may refuse only when he finds that the candidate does not meet the legal requirements. In any case, its decree loses effect when the SJC were to decide against it by a majority. Furthermore, if the President of the Republic does not decree the candidate within fifteen days, the one indicated by the SJC is elected ope legis.

$20 \%$ of Supreme Court judges are elected by Parliament from among lawyers, university professors and senior administration officials with over fifteen years of experience, who have at least the title of "PhD" in law and who have not carried out political functions in the last ten years?.

The figure of the Attorney General is also profoundly modified, who continues to be elected by Parliament with a majority of 3/5; however, the choice cannot be arbitrary but must only take place among candidates within a shortlist of three names proposed by the Superior Council of the Prosecutor's Office. To this end, the latter will have to issue a public call as part of a transparent procedure to identify the three most suitable candidates to be sent to Parliament. The Attorney General must have over fifteen years of experience and high moral and professional integrity. He must not have held political positions in the last ten years and must have either completed the School of the Judiciary, or have acquired the title of "research doctor" in law. If Parliament does not choose the Attorney General within thirty days of receiving the list, the one indicated first by the CSPO will be proclaimed by law. After the end of the mandate (which lasts seven years) he can choose whether to return to his previous job or be appointed judge at the Court of Appeal.

Its main prerogatives include the administration of powers of attorney, except for the special one; represents the accusation before the Supreme Court and the Constitutional Court, except in cases in which it is a matter of crimes for which the Special Prosecutor is competent. Unlike in the past, it cannot appoint, evaluate, transfer, apply disciplinary measures to prosecutors (these prerogatives have now passed to the CSPO). He may be dismissed from office by the Constitutional Court in the event of serious ethical or professional violations, or of definitive conviction for a crime (he is suspended, however, in the event of arrest, or when he assumes the capacity of defendant in criminal proceedings for a willful crime).

Unpublished and newly minted is the Council for Appointments in Justice. Composed of nine members chosen by lot from judges and prosecutors who have not received disciplinary convictions, it remains in office for one year. The task of the Appointments Council (article 149 / b cost.alb.) Is to verify the legal conditions and the professional and moral evaluation criteria of the candidates suitable to be elected members of the Constitutional Court or High Inspector of Justice.

The Constitutional Court is composed of nine members who remain in office for nine years (in any case the member of the Court ceases from office upon reaching the age of 70 ); they must have over fifteen years of experience as judges, prosecutors, lawyers, university professors, or senior government officials. Three will be elected by the President of the Republic, three by the Supreme Court, three by Parliament with a majority of 3/5 of all its members. Candidates will be chosen from those listed by the Nomination Council in Justice. With reference to those elected by Parliament, if the latter does not choose the candidate or candidates within thirty days of receipt of the list by the

${ }_{3}$ The members of the Supreme Court can be removed from their post by the SJC in the event of serious ethical or professional violations, or of definitive conviction for a crime (they are suspended, however, in the event of arrest, or when the quality of defendants in proceedings occurs penalties for willful crimes). Furthermore, the office is not compatible with others, except for those relating to university teaching. The decisions of the Supreme Court be published in a special series, with the dissenting opinions. It is expressly established (Article 141 of the Italian Civil Code) that its duties include the interpretation and application of the law to ensure the uniformity of decisions and jurisprudential practice. Furthermore, it is specified (paragraph 2) that when the Supreme Court decides to change the jurisprudential practice, it decides at the United Sections on certain issues decided by the individual colleges. 
Appointments Council, the candidate listed first will be automatically appointed (Article 125 of the Italian Constitution). The competences of the Court have remained almost unchanged, with the exception of letter $\mathrm{f}$ ) of article 131 of the alb. according to which every citizen can have recourse to it against judicial decisions that harm his fundamental rights provided for in the Constitution. It is too early to say, but the law will probably have a disruptive effect on the entire Albanian legal system. There is a real risk that the Constitutional Court becomes a fourth-degree judge to which to turn against the sentences of the Supreme Court, in this case creating a real conflict between the latter in its capacity as Court of legitimacy and the Constitutional Court itself. As it is structured, in addition to having a political nature in the evaluation of the laws of Parliament as well as judging institutional conflicts (its competences are identical to those of the Italian Constitutional Court), it risks being overwhelmed by the request of citizens who do not they will be satisfied with the decisions of the Supreme Court and will go to ask for further justice.

The High Inspector for Justice also represents an unprecedented novelty. Equalized by role to the judge of the Supreme Court and with a term of office of nine years without the possibility of reelection, his function should be to investigate and monitor the activity of (all) magistrates of any level (be these judges and prosecutors of first instance, that of the Constitutional Court, Supreme Court, SJC, CSPO etc.). He carries out the function of the accusation against them according to the procedures indicated above and others that will be provided for by the implementing laws. He is also competent for the inspection of courts and prosecutors (Qeleshi J - Skenderaj K. - Mengjesi S., 2017). A particular and detailed procedure is also envisaged for his election. First of all, he must be a distinguished jurist with no less than fifteen years of experience and with high moral and professional integrity (moreover he must not have held political positions in the last ten years). His appointment must take place from among a shortlist of five subjects indicated by the Council for Appointments in Justice through a transparent public procedure. If Parliament does not choose the candidate with a 3/5 majority within thirty days of receiving the list, the first classified will be appointed by law. His office is incompatible with others, except for those relating to didactic, academic and scientific activities (147 / ç cost.al.b). The end of his mandate (or the case of impossibility to carry it out) is declared in the context of a joint meeting by the SJC and CSPO. Instead, he should be dismissed by the Constitutional Court in the event of serious ethical or professional violations, or a definitive sentence for a crime (he is suspended, on the other hand, in the event of arrest, or when he assumes the capacity of defendant in a criminal proceeding for the commission of an intentional crime). The violations committed by the High Inspector for Justice will be investigated by a commission of inquiry appointed by the Parliament which presents its conclusions to the Constitutional Court (art. 147 / e cost. Alb.).

Finally, as regards the ordinary judiciary, all judges must undergo a public competition to access the School of the Judiciary (Article 136 / a of the Constitution), which must be passed through a special verification process. preliminary of their economic income and their figure. While the Albanian Constitution prohibits the creation of extraordinary prosecutors and courts, with the reform two new institutions have been established: the special prosecutor's office with its own special investigation unit and the special court. It is, in truth, the constitutionalisation of the already existing prosecutor and court for serious crimes, with the addition of some additional competences. The candidates are professional judges who will be chosen by a majority of the SJC (instead a 2/3 majority will be needed to remove them from office). They and their relatives will be subjected to periodic checks that will concern assets and bank accounts, as well as personal telecommunications (Article 135 of the Italian Constitution).

The same mechanism is provided for the special prosecutor's office and the special investigation unit (Article 148 of the Constitution alb), whose task will be, respectively, to investigate and judge organized crime and crimes committed by politicians (Bogdani, 2017). 


\section{Le New "Vetting" Institution}

In order to make the reform effective, Article 179 / b Disp. trans. fin. Constitution, provides for an articulated system - of a transitory nature - for the re-evaluation of the magistrates currently in service; this task that will have to be carried out by two new transitional bodies, namely the Independent Commission for the re-evaluation of magistrates and the Board of Appeal (the so-called "vetting" procedure), which will remain in office for five and nine years respectively. Created ad hoc, their function will be to re-evaluate all judges, of all levels.

The vetting members will enjoy the status of Supreme Court judges. Alongside the two commissions, the establishment of the International Monitoring Operation is planned, which will be composed of judges and public prosecutors. foreigners with at least 15 years of experience in their duties, who will be appointed by the Albanian government. Among the tasks of the latter, in addition to actively participating in the re-evaluation operations, there will also be that of giving indications to Parliament on the candidacies of the members of the Independent Commission for the re-evaluation of the judges and judges of the Board of Appeal. Meanwhile, in implementation of articles 178 et seq. of the Constitution (transitional and final provisions and related annex A, B, C, D) on 30.08.2016 the Parliament of the Republic of Albania - with only the votes of the majority - approved the ordinary law no. 86 on the "transitional reassessment of prosecutors and judges in the Republic of Albania" (law entered into force on 14.09.2016).

Particularly interesting is not only the evaluation procedure of the current magistrates by the Independent Commission and the Board of Appeal, but the preliminary phase that will precede their evaluation which will have to focus on three aspects; a) asset valuation; b) control of the figure (personal and family); c) evaluation of professional skills.

The investigation on the asset evaluation will have as its object the control of the assets of the magistrates and above all their lawful origin. The investigation on the control of the figure will reside in a three hundred and sixty degree investigation that will involve the personal profile of the individual magistrate, his acquaintances, his clarity of image. Finally, the assessment of professional skills will have as its object the control of the proper conduct of trials or investigations by judges and prosecutors. The last three years of professional activity will be subject to evaluation, which may however be extended to 1 January 2006 at the request of the Commissioner-Rapporteur or the international observers.

In addition to the formal investigation, the individual members of the Independent Commission for the reassessment of judges, the Board of Appeal, as well as the international experts for monitoring will be able to carry out further investigations than those just highlighted. They will be able to request information from banks and institutions, collect documents from criminal proceedings, collect information on well-known and commonly understood facts. International observers, then, will be able to independently collect evidence or documents which have full probative value. Instead, their written opinions presented to the Commission and the Board of Appeal can be taken into consideration but will not have the value of proof (art.49 L. 86/2016). They may also indicate to the Commission or the Board of Appeal further evidence to be acquired. The refusal of the latter must be made in writing with a reasoned deed. If the Commission were to consider the evidence sufficient, the magistrate will have the honor of proof to the contrary. The Commission may question the magistrate in a public hearing in the presence of international observers. Both will be able to ask specific questions to the same also on issues aimed at testing his practical abilities in the field of law in which he has exercised his duties in the last year.

\section{The Main Changes to the Code of Criminal Procedure. The Judge for the Preliminary Hearing}

As part of the overall reform plan, particular attention was paid to the need to modify and adapt the two main codes of criminal justice: the criminal code and the code of criminal procedure. With 
reference to the latter, attention was paid to the opportunity to carry out some important interventions capable of making the 1998 code of criminal procedure compatible with the reformed institutions such as the Supreme Court, the General Prosecutor's Office, the competent Prosecutor's Office for crimes of corruption and organized crime and the competent court for crimes relating to corruption and organized crime etc.

In this context, two new figures were also established within the criminal procedure code, namely that of the judge for preliminary investigations and the judge for the preliminary hearing. While the first was partly known to the pre-reform penal code, the second is from the new and unpublished tuotto. The same is inspired by the same figure provided for in the Italian criminal procedure code. Actually, the 1998 Albanian penal code is inspired by the Italian penal code even if at the time it was considered more appropriate not to incorporate the preliminary hearing judge into the code.

With reference to the judge for preliminary investigations, a specific office was not envisaged but it was believed that the competence regarding the guaranteed acts and precautionary measures belonged to the court. Specifically, the prosecutor asked the court to apply a measure against a suspect. In practice, the competent body was the civil court that dealt with such requests. This clearly led to quite a few problems. In fact, civil judges are not culturally and professionally equipped to deal with criminal matters. The civil judgment concerns the interpretation of acts, while the criminal one concerns the evaluation of facts. Therefore, the reform correctly aimed to create a specific figure within the criminal court with limited competences to control the activities of the public prosecutor.

However, despite the aims of the reform, the problem does not seem to have been resolved yet. With the exception of the Tirana district where the judge's office for preliminary investigations was set up within the criminal court, in the smaller districts decisions on the requests of prosecutors are also taken by civil judges. This is also due to the operation of the vetting bodies. The continued expulsion of judges and prosecutors from the justice system has led to an under-staffed situation of the judicial offices. Therefore, an effective judgment on the effects of the judge for criminal investigations can only be made when the Albanian justice machine is fully efficient in terms of staff. radical.

On the other hand, the reform regarding the figure of the judge of the preliminary hearing was

Until the reform, it was up to individual prosecutors to decide whether to dismiss a particular case or send it to trial before the court. What in theory responded to a logic of autonomy of the prosecutor's office with respect to the judicial bodies in compliance with the principle of separation of careers, had actually led to a very problematic situation. Prosecutors had become absolute rulers of investigations and therefore enjoyed a strong and unlimited discretion. This had fueled many suspicions regarding their honesty and probity. In fact, there were many cases of suspicious filings linked to suspected corruption for prosecutors.

In order to put a stop to such a situation, the introduction of an additional figure aimed at evaluating the work of the public prosecutor was considered essential. The judge for the preliminary hearing was therefore identified as the body capable of performing a similar function.

The latter is framed in a special office and has extensive powers on the requests of the prosecutor following the conclusion of the investigations for the crimes provided for by the criminal code. While for fines the public prosecutor can also decide whether or not to file an investigation in the plan, with reference to the crimes all his work is devolved to the scrutiny of the judge for the preliminary hearing.

In fact, it is up to the latter to control the investigation activities, the exceptions of the parties relating to nullity and territorial jurisdiction. It is the judge for the preliminary hearing who must judge the requests for dismissal by the public prosecutor, as well as it is up to him to decide if there are the reasons why the case goes to trial before the court for hearing or is definitively closed. . The same can then order new investigations when he believes that those of the public prosecutor are not sufficient or are unsuitable.

This is a new figure, therefore, central to the new Albanian criminal trial and which could have 
a significant impact on its structure.

\section{The Criminal Code Reform Project and Related Challenges}

For the complete reform of justice in Albania, alongside the reform of the criminal procedure code, a radical change in the penal code is indispensable. While it was considered appropriate to intervene with a massive sectoral reform on the code of criminal procedure, but which in any case does not affect its basic structure, with reference to the criminal code the conclusions of the experts were of different sign. The conclusion was reached that a modification, however profound, of the penal code could not be sufficient or even useful. Indeed, it would be more appropriate to proceed with the drafting of a new penal code (Bozheku, 2014) capable of responding to the actual needs of the social and legal reality of the Republic of Albania.

In this context, in 2019 a special commission was appointed headed by the Director of the Higher School of the Judiciary and aimed at creating a new code. To date, the results of the works have not been made public and therefore we are unable to express an opinion on the results achieved by the reform commission.

However, there are a series of problems of the Albanian penal code that are quite evident and that in any case must be placed at the center of the reflection of the jurists called to carry out its reform.

The current code suffers from a lack of coordination both within the general part and between this and the special part. The general part in fact represents a mismatch between concepts taken from the Italian, German and Albanian penal codes of the communist period (of 1978), with elements also taken from the Scandinavian and French codes. If we analyze, instead, the special part, the original structure is taken from the French penal code. Besti look, for example, at commissive offenses. As in the French code, these are all specifically provided for in the special part. And indeed, contrary to the Italian penal code, there is no equivalence clause in the general part that equates commissive offenses with commissive ones.

However, the various additions that the Albanian penal code has undergone over time do not respond to the logic of the French penal code, but follow that of the Italian penal code. In many cases, standards provided for in European directives are taken up and transported directly in the special part of the code. Many of these include elements that do not find valid references in the general part of the code. Basics think, for example, of the concept of intentional willful misconduct and specific willful misconduct. These connote many of the provisions introduced after 1995 and can be found in the various European directives, such as that relating to terrorism and terrorist financing, that relating to money laundering, etc. Well, if we analyze these norms, even in the absence of valid interpretative proposals from the doctrine, their dogmatic and interpretative framework is very complicated. In fact, it seems that they live alone without interacting with the general part of the code, which, on the other hand, should form the basis for their correct interpretation.

We could talk at length about the gaps and criticisms of the Albanian code. We promise to do it in a future paper. Limiting ourselves to just a few further examples, we can certainly underline the problem relating to the determinacy of criminal offenses. Already in the general part, the legislator never speaks of the fact of a crime, limiting ourselves to the generic category of crime. This omission is not a trivial matter, since criminal law concerns the assessment of facts which must be well established. In the absence of such a clarification in the general part, there are a series of very problematic cases in the special part. Just think of the provision on theft where, contrary to the communist code of 1978 or that of King Zog of 1930, the same is not defined. The case-by-case identification of the concept of theft is left to the discretion of the judge.

In a context, where there is a strong suspicion regarding the activity of magistrates, accused of excessive arbitrariness that hides the specter of corruption behind it, the issue takes on very problematic features. Excessive interpretative discretion left by the criminal law and above all by the interpretative system of the same, provided for by the general part, constitutes a vulnus that makes 
the current code unsuitable for the Albanian reality.

The code, consisting of a few rules, cannot be defined in itself as unsuitable. Probably in reality it is socially more stable and legally more consolidated it can be considered adequate. For example, such a code, consisting of few provisions, is found in Germany. However, in Germany doctrine and jurisprudence play a fundamental role in the correct interpretation and creation of law, supporting the legislator in the latter process. To give an example: if it is true that in Germany there is no provision that defines the causal link, German jurisprudence and doctrine have created a solid and accepted interpretative system that makes up for the lack of definition by the legislator.

In a cultural and legal reality such as the Albanian one, such a path is not conceivable. On the one hand, Albanian society is not yet culturally equipped to the point of uncritically accepting the decisions of the judges. In order to be accepted, the latter must first of all be based on the positive law provided for by the provisions of the criminal code and, secondly, they must be well motivated in such a way as not to leave doubts to suspects. Secondly, Albanian doctrine and jurisprudence is not yet solid.

In fact, there is a lack of doctrinal works or jurisprudential judgments capable of guaranteeing interpretative tranquility. Those few that are circulating are unable to take on the role of guide for the scientific community or of interpretative inspiration for the interpretations of court judges. The current scientific community is experiencing a moment of profound lethargy. In fact, it lacks solid and above all continuous legal works. In short, there is no cultural debate among academics on the hottest issues of criminal law. This is partly due to incompetence, partly due to laziness, partly due to lack of stimulus on the part of the new class of academics. However, such a situation greatly affects the code and its interpretation. The inertia of the doctrine, which does not feed the debate, favors the arbitrary interpretation by the judicial bodies on the practical point.

On the jurisprudential side, however, at least until the 2015 reform, the judges of the Supreme Court to whom the interpretation of the rules is reserved were politically appointed. Therefore, their interpretations were suspected of political uncontamination: suspicions also fueled by strong doubts about the professional qualities of the judges of this Court (Bozheku, 2014).

In this context, a code with few rules, also deprived of the support of the two main protagonists of its interpretation (doctrine and gurisprudence), can only be considered unsuitable and incompatible with the legal reality of the country.

In the face of these data, there is the idea that a good criminal code in Albania must be composed of a significant number of rules where the spaces for interpretation are limited. This is not to limit the prerrogatives of doctrine and jurisprudence, but rather to encourage the latter to engage in their continuous and systematic interpretation (Bozheku, 2014).

Paradoxically, a code with many provisions, which does not represent a more current technique that is actually legally sound like the Italian, German or Spanish one, in a context like the Albanian one could have many benefits.

In the first place, it would reduce arbitrary interpretations by the jurisprudence and this would lead to greater trust on the part of citizens towards it. Secondly, a code with a set of rules to refer to when interpreting, would allow greater control, including technical ones, on the work of the judges themselves in the assessment by their governing bodies (CJS and CSPO). In fact, if a magistrate (public prosecutor or judge) in his interpretations has not taken into account the provisions of the code, he may have a negative judgment of professionalism; and such a circumstance should prompt them to pay the utmost attention to the correct interpretation of the provisions of the code.

Thirdly, a code whose systematic nature is already proposed in detail by a shrewd and refined legislator, can only serve as a cultural driving force for the class of jurists and magistrates. In fact, the same would open a series of discussion tables no longer on how to create an interpretative system adequate to the provisions of the code, but, rather, on the correct interpretation of the systematic framework already offered by the legislator. By favoring dogmatics in this way - that is, the search for the deepest and most genuine truth that in criminal law can only be that of the most correct and adequate interpretation of the will of the historical legislator - one can arrive at a leap of cultural 
quality on the part of the interpretive world and which must accompany the new codicistic product.

\section{Conclusions}

Although 5 years have already passed since the modification of the constitution, it is still difficult to be able to express an opinion on the reform of justice in Albania. It will be time to highlight its strengths and weaknesses. Surely to be appreciated is the timing with which the reform was approved (in just a year and a half), as well as its basic idea: to restore citizens' trust in justice; reduce the influence of politics on it; fight the rampant phenomenon of corruption; favor the improvement of the personal and professional quality of the judges.

With reference to the latter aspect, with a view to restoring citizens' trust in the judiciary, the 2016 reform denotes the spasmodic desire to improve the image of the entire class (at all levels), primarily as men. Suffice it to think, in this regard, that many provisions provide for suspension from the performance of the assignment in relation to the hypothesis of mere initiation of disciplinary proceedings, or with the assumption of the status of suspect in an intentional criminal trial. The provisions that provide for the removal from office also with reference to criminal convictions for any crime, even if negligent, are also oriented in the same direction, or in the case of conducts that damage the image of the institution they represent. These are cultural norms, aimed at affirming cardinal values such as honesty, professionalism, ethical-moral composure, a sense of duty, respect for institutions, etc. However, beyond the contingent reasons that animate them, these are rules that can take on dangerous nuances, especially if examined in a long and medium-term perspective. The mechanisms for hitting the top of the institutions of justice are too easy and therefore are easily prone to crippling. Few initiatives by troubled prosecutors would be enough to bring all the institutions to their knees and make senior officials of the judicial system forfeit their posts.

That said, the reduction (if not the exclusion) of the influence of politics on the judiciary cannot fail to be welcomed. The latter will be self-governing: even in the cases in which the intervention of the Parliament or the President of the Republic is envisaged, such as, for example, in the choice of top management bodies such as the members of the Superior Judicial Council and the Prosecutor's Office, the Supreme Court, the Constitutional Court, the Attorney General, the High Inspector for Justice, their power is not only severely limited, but must be exercised wisely and within a reasonable time. For their choice, the new Constitution provides for a dynamic process which, unlike in the past, cannot experience moments of stalemate. For example, the appointment of the Supreme Court judges must be carried out by the President of the Republic within ten days of receiving the list of names chosen by the Superior Judging Council, who will be able to approve the choice of candidates en bloc even if there is rejection by of the President. A similar process is envisaged for the choice of the Attorney General: the list of three names chosen by the Superior Council of the Prosecutor following the call for a public procedure is sent to Parliament; in the event that Parliament does not choose the candidate within thirty days with a majority of three fifths of its members, the one indicated as first on the list by the CSPO will be appointed by law.

The same automatism also applies to the members of the Constitutional Court and the High Inspector of Justice. The Council for Appointments in Justice, appointed annually (on December 5) by the President of the Republic from among magistrates of all levels, following a public procedure, indicates the list of suitable names; if the members are not promptly approved, those listed by the Board for Appointments will be appointed by law.

In short, the whole new Constitution provides for automatisms to avoid deadlock situations and at the same time procedures which, at least in the abstract, should guarantee the possibility of participating (and possibly accessing) the most important and delicate offices of justice to those who enjoy a personal and professional background of the highest level.

At the same time, however, it highlights the profound immaturity that has enveloped Albanian politics for decades, which has proved incapable of carrying out its power to choose the leaders of the justice system with righteousness and balance: it is an undisputed fact that the previous system that 
entrusted the administration of justice to politics was a failure! Then a new path will be experimented that sees politics and the judiciary as protagonists, who will be called to find balance points in choosing the best men (partly among magistrates and partly among jurists) for the direction of the top bodies of the judicial system. However, their positions cannot be considered equal: it will be the magistrates who will indicate to politics the subjects they deem suitable to assume top positions within them. If the policy fails to find balance points on the indications coming from the judiciary, the choices made by the magistrates themselves will prevail.

What will all this bring?

It is difficult to be able to make predictions.

On the political front, it can reasonably be argued that there will be much more maturity and attention on the part of the political class (all) in promptly and well exercising their prerogatives in matters of justice, in order not to leave the field to automatic rewarding choices. indicated by the magistrates. A policy that can participate in the administration of justice "on time" should reasonably become aware of the fact that the possibility of being able to make shared choices, capable of constructively affecting the balance of the judiciary, represents a guarantee for itself to avoid that the judiciary becomes too independent and therefore able to influence politics. Therefore, with the automatisms provided for in the Constitution, the message that is sent to the political class is simple: carry out shared choices between yourself and with the judiciary on the best men, since otherwise the names chosen by the magistrates will prevail.

On the judiciary front, the reasoning becomes more complex.

On the one hand, the magistrates will certainly be free from political control. This could lead to an overall improvement in justice in the short term. There will be greater attention especially with reference to the crimes committed by the so-called White collars. With its reorganization and above all through its proper conduct, the aim is to progressively improve the work of all state institutions. This should lead to an increase in criminal investigations and trials of those who have committed crimes and who, to date, have enjoyed easy impunity. It will be the task of the judiciary who emerged from the "caudine gallows" of "vetting" to assume the functions of the same "vetting" (which in truth are those of the judiciary) investigating and judging politicians and public administrators who have committed corruption or other crimes (Bozheku, 2016).

If everything goes well, at least in the short-medium term, improvements will be appreciated: justice will probably work again (it is believed) and it will be (it is hoped) equal and fair for everyone.

However, it remains to be seen what will happen over a longer time frame. In fact, the risk that judges and public prosecutors take over and condition the choices of the same policy. A few lines back we have already expressed several doubts about the rules of the reformed Constitution which provide for the suspension or even the dismissal of magistrates who hold high offices (Constitutional Court, Court of Cassation, SJC, CSPO, etc.) subjected to criminal trials, disciplinary proceedings, etc. ., to the extent that they are preparing for easy manipulations and, therefore, could lead - at least in the abstract - to adventurous as well as factious judicial initiatives with devastating effects. And if this could, in hypothesis, happen within the same category (the magistrates in fact), the scenario with reference to political-judicial relations could become even more worrying. If until now the judiciary has had its hands tied in the face of political choices, one day later, thanks to its independence, it could affect the correct exercise of political power through investigations and judicial scandals (Bozheku, 2017). On the other hand, the greater number of professional members than those elected by Parliament within the CSG and CSP if, on the one hand, it guarantees the full autonomy and independence of judges and prosecutors, on the other, it can lead to the formation of currents within the two magistracies, just as happened in Italy (which is seen, for better or for worse, as an example to follow on the other side of the Adriatic!).

Probably, however, the total separation of careers between judges and prosecutors (the Constitution does not even provide for the reciprocal appointment of their members in one or the other Superior Council) could constitute a bulwark capable of preventing the system from degenerating ( this time backwards, with the judiciary able to guide the choices of politics), given 
that - at least in the abstract - political inquiries by zealous PM they should not find fertile ground in the court benches. And if we add to this the possibility of politics (in particular of Parliament and the President of the Republic) to be able to participate conscientiously, finding balance points within it (within well-identified time limits), in the choice of key figures such as the Attorney General, the High Inspector for Justice, the members of the Supreme Court, the Constitutional Court, it can be said that - at least in the abstract - the system has sufficient check \& ballance mechanisms. The sharing of choices on some key figures of the system between the two judges and political power can in fact lead to the right balance that make the system effectively effective.

Finally, coming to the two codes and related reforms.

The deeply modified code of criminal procedure constitutes a challenge to understand how effective the reform will be in point of fact. In fact, the new provisions will be applied by the new judges and the new justice system that came out after the reform (and after the vetting was examined). The massive changes and the introduction of the new figure of the judge for preliminary investigations should lead to an overall improvement of the system. Prosecutors will be subjected to greater, more penetrating and autonomous checks by the judicial bodies. And this should lead to both an improvement in the quality of investigations and an almost total decrease in the decisionmaking discretion on the part of prosecutors. That is, however, provided that there is an overall improvement in the quality of the entire class of magistrates, both these prosecutors and judges. This, in fact, constitutes the central fact and the real challenge of the reform. If the quality of the judges does not improve, both in terms of knowledge of the rules and their correct interpretation and in terms of their exact application, it is unlikely that the reform will lead to the desired results. Even in terms of the challenge against corruption in judicial circles, the increase in quality is the real turning point and the real challenge (Bozheku, 2014). If this does not happen, it would only risk shifting the problem from the figure of the public prosecutor to that of the judge of the preliminary hearing, without leading to any effective and adequate solution.

With reference to the criminal code, the work of the reform commission established in 2019 is awaited with great curiosity. Currently we can only hope that they will be addressed in the path we have just outlined. In particular, in order for a new penal code to be truly defined in line with the reforming spirit of the legislator in recent years, it must respond to the current doctrinal and jurisprudential reality of the country, which, after 30 years of transition also juridical, they require a stability and solidity that only the legislator can give through the creation of a modern and welldetailed penal code (Bozheku, 2014). By assuming the guiding role of the legal system through the creation of a capillary work with deep and broad content, the legislator would become the engine that would fuel a new interpretative and above all dogmatic season within doctrine and jurisprudence. Faced with a well-organized and detailed work, the former could not escape its task of making dogmatics the pivot for the correct interpretation of the code. The second, however, in the face of a code that offers very clear and precise interpretative coordinates, could no longer take place in curious and at the same time suspicious interpretations of individual criminal offenses. In such a context, the sure winner would be only one: the justice!

\section{References.}

Agaçi, E. (2017). Novità del sistema di giustizia in Albania. Vetting e altre misure per il restauro della fiducia in pubblico, in La riforma costituzionale ("strutturale”) del sistema della giustizia nella Repubblica d'Albania, edit from Bozheku-Spangher-Hoxha, Edizioni Nuova Cultura, Rome.

Belfiore, E. (2008). La disciplina dell'ignorantia legis nel codice penale albanese alcune considerazioni, in Il codice penale Albanese, a cura di Vinciguerra, Cedam, Padova.

Bogdani, M. (2008). Fighting Corruption and Organised Crime in Albania Through SPAK authirities noveltieson Costitutional and Legal approach in reflection of best international standards and practices in La riforma costituzionale ("strutturale") del sistema della giustizia nella Repubblica d'Albania, edit from BozhekuSpangher-Hoxha, Edizioni Nuova Cultura, Rome. 
Bozheku, E. (2013). Le problematiche del sistema penalistico albanese: un panoramico sguardo d'insieme, in AA. VV., Scritti in onore di Alfonso M. Stile, Edizioni Scientifiche Italiane, Napoli.

Bozheku, E. (2014). Ide, mendime dhe reflektime lidhur me nevojat dhe masat që duhet dhe mund të merren në kuadrin e reformimit të sistemit të drejtësisë - veçanerisht asaj penale - në Shqipëri, in Illyrius, 4.

Bozheku, E. (2014). Le problematiche del sistema penalistico albanese: un panoramico sguardo d'insieme, in archivio penale (web), I.

Bozheku, E. (2016). Chiose a caldo sulla riforma costituzionale del sistema giudiziario in Albania, Illyrius, 7(II).

Bozheku, E. (2016). La riforma costituzionale ("strutturale”) del sistema della giustizia nella Repubblica d'Albania, in diritto penale contemporaneo.

Bozheku, E. (2017). Alcune osservazioni sparse sul progetto di riforma del codice penale della Repubblica d'Albania, in La riforma costituzionale ("strutturale") del sistema della giustizia nella Repubblica d'Albania, edit from Bozheku-Spangher-Hoxha, Edizioni Nuova Cultura, Rome.

Commission of Venice, Report on the Albanian justice CDL-AD (2010) 040

European Commission, 2014 Progressive Report for Albania.

Elezi, I., Elezi, E. (2010). Zhvillimi i mendimit teoriko - juridik shqiptar, Shtepia Botuese e Librit Universitar, Tirane, 2010.

Elezi, I., Elezi, E. (2010). Histori e se drejtes penale, Shtepia Botuesee Librit Universitar, Tirane.

Fondaroli, D. (2008). Appunti sulla confisca nel codice penale della Repubblica d'Albania, in Il codice penale Albanese, a cura di Vinciguerra, Cedam, Padova.

Jahjolli, G. (2014). Problematikat e Sistemit penal dhe atij procedural penal në Shqipëri, in Illyirius, 4.

Liguori, H., Hoxha, A. (2017). La riforma del codice di procedura penale del sistema giudiziario in Albania. I procedimenti speciali: spunti di riflessione, in La riforma costituzionale ("strutturale") del sistema della giustizia nella Repubblica d'Albania, edit from Bozheku-Spangher-Hoxha, Edizioni Nuova Cultura, Rome.

Pelissero, M. (2008). I reati politici nella codificazione penale albanese, in Il codice penale Albanese, a cura di Vinciguerra, Cedam, Padova.

Pittaro, P. (2006). Il codice penale albanese: un'introduzione, in Dir. pen. XXI sec..

Qeleshi, J., Skenderaj, K., Mengjesi, S. (2017). Prosecution under the new regulation in Albania, in La riforma costituzionale ("strutturale") del sistema della giustizia nella Repubblica d'Albania, edit from BozhekuSpangher-Hoxha, Edizioni Nuova Cultura, Rome.

Rossi, A. (2008). Note sugli illeciti penale dell'economia nel sistema del codice penale della Repubblica d'Albania, in Il codice penale Albanese, a cura di Vinciguerra, Cedam, Padova.

Spangher, G. (2017). Brevissime considerazioni sulle modifiche del sistema giudiziario in Albania, in La riforma costituzionale ("strutturale") del sistema della giustizia nella Repubblica d'Albania, edit from BozhekuSpangher-Hoxha, Edizioni Nuova Cultura, Rome. 